\title{
Strengthening Community Food Security through Posyandu Cadre and Midwife Empowerment Action Program
}

\author{
Tejasari", Nuryadi*, Dewi Rokhmah ${ }^{*}$ \\ \# Agricultural Technology Faculty, Jember University, Jember 68121 Indonesia \\ E-mail: tejaharto@yahoo.com \\ * Community Health Faculty, Jember University, Jember 68121 Indonesia
}

\begin{abstract}
Community food security means fulfilment of energy and nutrients of every community member from daily food consumption intake. Non-fulfilment of these requirements led to the incidence of malnutrition in the community, which marked by the emergence of nutritional problems among the nutrition vulnerable groups, such as low body weight of under five years olds children, malnourished including stunting children. Food and nutritional insights of the community program actors, such as posyandu and nutrition cadres, and midwives plays an important role in efforts to prevent and repair the problem of malnutrition in young children, especially from the lower to middle income groups. Therefore, empowerment posyandu cadres, nutrition cadres, and midwives through briefing mastery of knowledge (cognitive competence) food, nutrition, and nutritional status, is the critical point of community food security. The purpose of this descriptive pre-post design study is evaluate the effect of the short nutrition class program on the increase of food, nutrition, and health knowledge of posyandu cadres, nutrition cadres, and midwives who play an important roles in handling the vulnerable malnourished families with infant and under fives children whose body weight below the red line standard (BGM) or stunting. The cadre and midwives subject was selected from the high stunting problem villages in the Sumbersari district in Jember. By 75 percent of active posyandu cadre and all midwife in the high prevalence malnourished regencies were selected as subject. After following the action program of nutrition class about nutritious food for the family, most of participants $(80 \%)$ increased their food nutritional insights. Similarly, after participated in pregnancy nutrition class program, the insight knowledge of the majority $(\mathbf{9 5 \%})$ of the midwives on pregnancy nutrition increased, proper and correct. After attending the balanced nutrition class by 75 percent of subject increased insight of balanced diet for family.
\end{abstract}

Keywords - Community food security; posyandu; nutrition cadre; midwife; low body weight children, vulnerable under nourished family, food health and nutrition knowledge.

\section{INTRODUCTION}

Community health and nutrition problems indicated by the prevalence of under nourished children, since this toddler group are sensitive to lack of energy and nutrients from daily food consumption. Un fulfillment of energy and nutrient requirement led to growth retardation, low productivity in adult, and finally lowering human quality index. Protein-energy malnutrition and micronutrient deficiency leading to early growth failure often can be traced to poor maternal nutritional and health care before and during pregnancy, resulting in intrauterine growth retardation and children born with low birth weight. Stunted children highly risk of non-communicable diseases later in life.

Global under nutrition problem are about 17 percent underweight pre-school children and 28.5 per cent stunted children. Under nutrition problem in Indonesia as shown by data from Basic Health Research or Riskesdas [1] done by the health ministry in 2013, reveal that the prevalence of under nourished children is on the rise. About 19 per cent (a rise from 17.9 per cent in 2010) children are malnourished, and 37.2 per cent are stunted (two per cent rise from previous research in 2010). Similarly, World Bank report called "The Double Burden of Malnutrition in Indonesia" published in mid 2013 which states that 36 per cent of children under the age of five in Indonesia suffer from stunted growth, part of 165 million children worldwide.

Indonesia has high wasting rates (excessively thin), second only to Timor Leste and higher than other poorer Southeast Asian countries such as Cambodia, Laos, Vietnam and Papua New Guinea. The highest prevalence of stunting is found in the East Nusa Tenggara province, where more than 50 per cent of children are stunted. Annual health report data from Jember Health Office [2] shows that in 2012 , there are 40 percent underweight, and 23 percent 
stunted children. These figure of high under nutrition prevalence shows community and national food security problems that need for solving.

The etiology of childhood under nutrition is complex involving interactions of multiple determinants that include biological, cultural and socio-economic influences. Basically, the root cause of the under nutrition problem lies in the cycle of poverty in community. Poverty tends to result in stunted growth children. Stunted growth is a result of maternal malnutrition commonly found in the country's poorest areas. Indonesian Statistics Agency (BPS) said the number of poor reaches more than 28 million [3]. The practice of breastfeeding is one major socio cultural factor of the cause problem. Indonesian Basic Health Research in 2010 reported that only 15 per cent of infants are exclusively breastfed for the first six months of life, as recommended by the World Health Organization (WHO) and The United Nations Children's Fund (UNICEF). In addition, only 43.9 per cent of children start breastfeeding within an hour of birth and 64.6 per cent receive a pre lacteal feed.

Indonesian health ministry already intervened various program to improve children's nutrition, i.e by promoting breastfeeding program, mass distribution of vitamin $\mathrm{A}$ as well as promoting the use of iodine in salt, that primarily conducted at an integrated health service post, well known as Posyandu where mother carrying their babies for free checkups body weight and height monthly. At this place, posyandu cadre, nutrition cadre, and midwives help mother especially who having under weight and stunting children that covered more than eight million malnourished children in Indonesia, especially from poor family. The cadre and midwives at Posyandu plays an important roles in assisting the mother for solving the problem of food consumption, complementary food, balanced diet, pregnancy, and breastfeeding.

\section{METHODS}

This crossectional pre and post treatment study was conducted in three stages, i.e : A) in depth problem analysis, B) treatment in the form of learning activity in class, C) evaluation the nutritional knowledge and skills. The study was done for 6 months in 2014 at the two vulnerable food and nutrition villages in Sumbersari District, Jember. About 75 percent of health workers that are posyandu cadre, nutrition cadre, and all midwives from two villages (Kebonsari and Kranjingan, Jember) with high current infant malnutrition problem were selected as respondent of this study They attended in the nutrition learning activities that over knowledge of the relationship of food, health, and nutrition, which consists of nutritious food groups, balanced diet, supplement food for infant, mother and pregnancy nutrition materials, respectively [4]. The nutritional knowledge and skills of the subjects was evaluated by pre and post evaluation using questionnaire and authentic assessment.

\section{A. In Depth Nutrition Food Problem Analysis}

Your paper must use a page size corresponding to A4 which is $210 \mathrm{~mm}$ (8.27") wide and $297 \mathrm{~mm}$ (11.69") long. The margins must be set as follows:
Priority public health and nutrition problems in the two villages is determined based on the in depth problem analysis directly and discussed with the headman, midwives, PKK, and maternal nutrition cadres in high BGM integrated health centre in March and mid-April 2013. Problem priority encountered are: 1) limited competence posyandu cadres and cadres of nutrition in providing nutritional counceling related $\mathrm{BGM}$; 2) lack of knowledge of the relationship of food nutrition, pregnancy, and breastfeeding with maternal nutritional status of children, and health; 3) lack of knowledge of family Prone Nutrition about balanced nutrition and low access to nutritionally balanced food.

The problem analysis data collected was presented to the village chief, and through discussions, the headman agreed that it is necessary to increase the competence of cadres nutrition, and midwives at health center, as well as undernourished households. Priority issues to be addressed through this learning activities was agreed upon as support five years strategic issues for health development program in Jember, especially lowering child and mother mortality and under nutrition children, increasing the number of wellnutrition knowledge family (kadarzi), and improving public health. In addition, the programs agreed to support the purpose of the Food and Nutrition Action Plan of East Java province, namely reducing the prevalence of malnutrition to $15 \%$ [5]. The public health nutrition parameters greatly determine the quality of human resources or the human development index (HDI).

\section{B. Food, health, and nutrition learning class}

The food, health and nutrition class that had been carried out are Food Nutrition class on May 17, 2014 attended by 37 posyandu cadre in Kebonsari ; 2) Pregnancy Nutrition Class on June 26, 2014 attended by 18 midwive subject in Sumbersari; and 3) Balanced Nutrition Class and Complementary feeding class on 28 November 2014 followed by a number of 30 mothers who composed of nutrition cadres, health worker, Dasa Wisma member, PKK member, mother's BGM toddler.

\section{Evaluation of food nutritional knowledge and skills}

The questionnaire used for evaluate the knowledge of midwife composed of five major aspects i.e are the window of opportunity concept, relationship between nutrition and low birth weight (LBW), the need of additional energy and nutrients during pregnancy, energy, protein, iron, and folic acid needs for pregnant women, function of protein, iron, and folic acid in the development of the mother's pregnancy. The questionnaire used for evaluate the knowledge of posyandu and nutrition cadre consists of five major basic knowledge, i.e food function, kinds of food rich in body building, regulatory and maintaining, energy source [6], complementary food [7] [8], and nutrition Balanced [9]. The evaluation was done before and after attending nutrition class.

\section{RESULT AND DISCUSSION}

\section{A. Regency Profiles}

Sumbersari sub district, which is located $3 \mathrm{~km}$ from the district, and $2 \mathrm{~km}$ from the district of Jember has population 
of 28964 people (year 2011), the second most populous (3408.34 inhabitants/km2), with the second-highest growth rate $(1.36 \%)$ [10]. Community groups a number of 139 people aged 0-12 and 1,480 children under five. (2009), and 14,050 age. As for the number of heads of families of some 7241 households (2011).

The health status of the Kebonsari community in 2012 as follows: Infant mortality is the number of babies born as many as 1,629 people, and the number of infants dying of 8 people (in 2011). Nutrition and mortality among children under five is composed of as many as 1,629 people, the number of malnourished children do not exist, and a number of good nutrition as many as 1,629 people. Immunization coverage is composed of 418 people polio immunization coverage, coverage of DPT-1 as many as 412 people, and BCG immunization coverage as much as 403 people. Life expectancy is 71 years. Latrine ownership consists of the number of households with latrines / toilets as many as 5845 households, while not having as many as 1,383 household latrines, and users as much as 25 household latrines.

The health status of the Kranjingan community in 2012 as follows: Infant mortality is composed of the number of babies born as many as 16 people, and the number of dead babies as many as 10 people. Pregnant women who received iron pills $(\mathrm{Fe})$ as much as 538 people. Nutrition and mortality among children under five is composed of as many as 1,140 people, the number of malnourished children of 7 people, the number of good nutrition as many as 1,133 people. Immunization coverage is composed of 724 people polio immunization coverage, coverage of DPT-1 217 people, and BCG immunization coverage by 178 people. Coverage of subsistence consists of total households can access clean water as much as 3,875 RT, pump well water users as much as $55 \mathrm{RT}$, users wells of $420 \mathrm{RT}$, and users springs as much as 7 RT. Latrine ownership consists of the number of households with latrines / toilets as many as 3,870 households, while that does not have as much as 13 household latrines, and no MCK users. Standby rural development consists of their rural community forum, the existence of which carry poskesdes SMD and MMD, UKBM (Posyandu pratama no, Posyandu associate as many as 11 pieces, health center full of 4 pieces, self-contained health center as much as 1 piece, Posyandu cadre of 60 people, their innovative activities such as class health centre pregnant women), the existence of community-based surveillance (Kadarzi, PHBs, periodic monitoring of larva). Improve nutrition of 1,156 infants and toddlers consist of the number of infants and toddlers who have body weight control card or KMS are 1,106 people, the number of infants and toddlers come to the health centre as much as 823 people, and the number of infants and toddlers who increase their body weight were 572 people.

\section{B. Subject Profiles}

All of the cadre subject were women and most of them are in productive age. Most of the subjects were housewives, high school educated, and has been a cadre of more than two years. Most midwife are young aged 20-30 years old, educated (diploma 3), and have been being midwife over three years. Profiles in detail are prented in Table 1.
TABLE I

RESPONDENT SUBJECT PROFILE

\begin{tabular}{|c|c|c|c|c|c|c|c|}
\hline \multirow{2}{*}{ Identity } & \multirow{2}{*}{ Type } & \multicolumn{2}{|c|}{$\begin{array}{l}\text { Posyandu } \\
\text { Cadre }\end{array}$} & \multicolumn{2}{|c|}{$\begin{array}{c}\text { Nutrition } \\
\text { Cadre }\end{array}$} & \multicolumn{2}{|c|}{ Midwife } \\
\hline & & No & $\%$ & No & $\%$ & No & $\%$ \\
\hline \multirow{2}{*}{ Gender } & Female & 30 & 100 & 31 & 100 & 11 & 100 \\
\hline & Man & 0 & 0 & 0 & 0 & 0 & 0 \\
\hline \multirow{4}{*}{ Age } & $21-30$ & 9 & 30 & 4 & 13 & 6 & 60 \\
\hline & $31-40$ & 12 & 40 & 14 & 45 & 3 & 30 \\
\hline & $41-50$ & 9 & 30 & 10 & 32 & 2 & 20 \\
\hline & $>50$ & 0 & 0 & 3 & 9.7 & 0 & 0 \\
\hline \multirow{2}{*}{ Religion } & Islam & 30 & 100 & 31 & 100 & 8 & 80 \\
\hline & Christian & 0 & 0 & 0 & 0 & 3 & 30 \\
\hline \multirow{5}{*}{ Education } & Elementary & 10 & 33.3 & 1 & 3.3 & 0 & 0 \\
\hline & Secondary & 3 & 10 & 2 & 6.7 & 0 & 0 \\
\hline & \begin{tabular}{|l} 
High \\
School \\
\end{tabular} & 13 & 43.3 & 22 & 71 & 0 & 0 \\
\hline & \begin{tabular}{|l|} 
D3 \\
\end{tabular} & 1 & 3.4 & 4 & 13.3 & 10 & 90 \\
\hline & S1 & 3 & 10 & 2 & 6.7 & 1 & 10 \\
\hline \multirow{4}{*}{\begin{tabular}{|l} 
Having a \\
baby or \\
toddler \\
and \\
Being \\
Midwife \\
\end{tabular}} & $<1$ year & 10 & 33 & - & - & 3 & 30 \\
\hline & 13 years old & 6 & 20 & - & - & 2 & 20 \\
\hline & $>3$ years & 8 & 27 & - & - & 6 & 50 \\
\hline & Dont Have & 6 & 20 & - & - & - & - \\
\hline \multirow[t]{2}{*}{$\begin{array}{l}\text { Being } \\
\text { Cadre }\end{array}$} & $<2$ years & & & 5 & 16.1 & & \\
\hline & $>2$ years & & & 26 & 83.9 & & \\
\hline
\end{tabular}

\section{Cadre's Nutrition Knowledge}

The subject cadre got more information about food, kinds of food, fresh and processed food that cadre can selected for the family under limited finance. The item of the nutrition knowledge evaluated are presented in Table 2.

The cadre's insight about nutritious food increased by an average of 40 percent. The highest increase in insight as much as 9 points, or 0.3 percent increase. The highest increase in insight contained in the answers on fresh food sample followed by examples of food sources of regulators. Most questions about the food sample that gave all necessary nutrient, can be answered by the majority of the participants before and after the nutrition class.

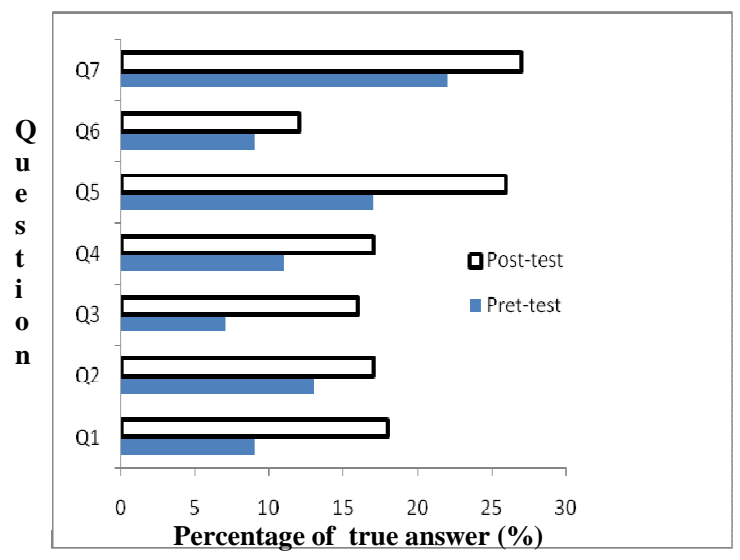

Fig 1. The increase of cadre's nutrition knowledge 


\section{Midwive's Pregnancy Nutrition Knowledge}

Midwives became aware that 1000 first days life is an important period from pregnancy until the age of 2 years which determined the length of the period of the next rest period of life, that called as window of opportunity. This period consider as a chance for fulfil necessary nutrients from fetus to adulthood .

They also got depth knowledge about the relationship between nutrition and low birth weight (LBW). Less nutritional intake increases the risk of low birth weight, as well as infectious diseases or concomitant. Therefore, LBW infants indicate that nutrition of pregnant women were less.

Midwives got to know that during pregnancy, the baby was conceived in need of energy and nutrients for the growth and development of the fetus. Therefor, a pregnant woman requires extra energy to function fetal growth. The amount of energy and nutrient needs of protein, iron, and folic acid pregnant women are Protein $=75 \mathrm{~g} / \mathrm{hr}+300 \mathrm{~g} ;$ Iron $=27$ $\mathrm{g} / \mathrm{hr}+30-50 \mathrm{~g}$, Folic acid $=200 \mathrm{mg}$ during pregnancy.

All learning nutrition class activities that have been implemented in this study are considered beneficial for posyandu cadres and cadres nutrition, midwives. The seriousness is evident from the many questions submitted during the class. In addition, there is a demand for the class continuously in the future. The increase knowledge of the cadre and midwives may support the MDG's goals in decreasing maternal death and stunting children [11].

\section{CONCLUSIONS}

The Food Nutrition class conducted in this study, increased food nutritional insights of most (80\%) of cadre. The learning nutrition class increased nutrition knowledge insight of posyandu cadres and nutrition cadres by 40 per cent. These increase knowledge are necessary for nutrition education activities for mothers and their low body weight and toddlers or BGM and stunted children in integrated health centre or posyandu. These knowledge has become a strenght of cadre in performing tasks in table IV for nutrition counseling and growth monitoring monthly.

After attending learning nutrition class of Balanced Nutrition, 75 percent of posyandu cadre subject increased insight about balanced diet for family. About 95 percent of midwife increased their knowledge about pregnancy nutrition, nutrition cycle, including breastfeeding and the advantage of mothers breast milk in preventing wasting and stunting children. Midwife become more aware about the important of Nutrition in 1000 first days of life, especially useful in motivating pregnant women who served in the health centre monthly.

\section{ACKNOWLEDGMENT}

These study was performed under competitive grant program from Directorate General of High Education, Ministry of Education and Culture Republic Indonesia, in 2014.

\section{REFERENCES}

[1] Balitbangkes, Riset Kesehatan Dasar, Jakrta Indonesia, 2013.

[2] Nutrition Department of Health Office, Nutrition and Health Annual Report of Jember, Health Office, 2013.

[3] BPS Kabupaten Jember, Kabupaten Jember Dalam Angka. BPS Kabupaten Jember, 2012.

[4] Tejasari, Training Modul on Food Nutrition and Health, Jember University Press, 2013.

[5] RAD PG Jatim, Food and Nutrition Action Plan of East Java Province 2013-2015, Pemprov Jatim, 2011.

[6] Tejasari, Nilai Gizi PAngan, C.V. Graha Ilmu, Yogyakarta, 2005.

[7] BPOM, MP-ASI. Jakarta, 1995.

[8] Depkes, Spesifikasi Teknis Makanan Pelengkap ASI. Jakarta, 2003

[9] Soekirman, Gizi Seimbang. (electronic article), 2011.

[10] DDA, Kabupaten Jember dalam Angka. Kabupaten Jember, 2012.

[11] R.I, Kebijakan Perbaikan Gizi Masyarakat di Indonesia. Jakarta, 2012 . 